高分子化学 (Kobunshi Kagaku), Vol. 28, No. 311, pp 266-272 (Mar., 1971)

$$
\text { クレーによるメタクリル酸メチルの重合 }
$$

第 2 報 クレーによるメタクリル酸メチル過酸化物の吸着について

（1970年 9 月 30 日受理）

松本恒隆*・宗 伊佐雄*・木村孝徳*

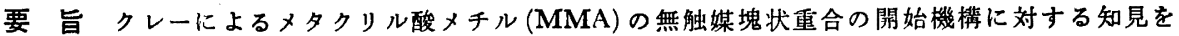
得るため, クレーに対する MMA 過酸化物の吸着現象を詳細に検討し, 次の結果を得た。(1) 重 合は $\mathrm{pH}$ 3〜5 の酸性を示すクレーのみで可能であった。(2) クレーに対する MMA 過酸化物の吸 着はクレーの $\mathrm{pH}$ に関保なくよく起こった。また， MMA 過酸化物吸着クレーをアセトンおよびへ ンゼンで抽出した場合，アセトンでは吸着量のほぼ 2 倍の MMA 過酸化物が抽出されたが，ペン ゼンではほとんど抽出されなかった。(3) 系中の過酸化物初濃度およびクレー量の增加とともにク レーに対する MM4 過酸化物の吸着量およびアセトンによる抽出量はともに增加した。(4)クレ 一の $\mathrm{pH}$ が酸性になるほど吸着量に対する抽出量の割合は著しく增大したが，吸湿クレーではその 值は酸性領域で著しく小さくなった。また酸性クレーでは水が存在するとクレー中の過酸化物の分 解速度は非常に大きかったが, 塩基性クレーでは水の有無に関係なく分解速度は小さかった。

以上の諸事実から， MMA 過酸化物は容易にクレーに吸着され，クレーのラメラ間隙ではさら に新たな過酸化物が生成されること,およびこれらの過酸化物は酸性のときのみ, 水の存在下で著 しく分解することがわかった。これらの事実とクレーによる MMAの重合性, すなわち, クレー, 水，MM4過酸化物によって重合が促進されることとはよい相関関係にあることを認めた。
\end{abstract}

\section{1. 緒言}

最近，クレーによるビニルモノマーの重合に関する研 究が二,三報告されている1) 。 。われわれも酸性白土に よるスチレン4) およびメタクリル酸メチル (MMA) ${ }^{5)}$ の 重合が可能であることを認め, スチレンについてはカチ オン機構で, MMAについてはラジカル機構で重合が進 行することを認めた。

特に，クレーによる MMA の重合にお゙いて，重合速 度はクレー量, 水分含有量, $\mathrm{MMA}$ 過酸化物量の増大と

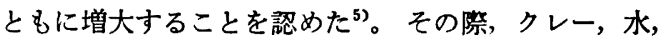
MMA 過酸化物の三者が密接に関連して重合速度の増大 を招来しており，いずれの1成分が久けても重合速度は 著しく低下した。また，同時に，クレーに対して MMA 過酸化物が吸着する現象を認め，この吸着現象がクレー による MMA の重合開始機構を考察するにあたって重 要な因子となるであろうことを示唆した。しかしなが ら, 重合機構の詳細は不明であり, 酸性白土の種類によ って必ずしも再現性のある結果を得ることはできなかっ た。

そこで，本報告では，まず，酸性白土の種類によって

* 神戸大学工学部工業化学教室（神戸市湤区六甲台 町)
重合性の異なる原因について検討した。ついで，クレー に対する MMA 過酸化物の吸着現象を重合開始能に相 違のある酸性クレーおよび塩基性クレーについて検討 し, クレー量, MMA 過酸化物湌度, 水添加量, 系の $\mathrm{pH}$ などを変化させた場合の吸着現象とクレーによる MMA の重合性との関係を明確にし，クレーによる MMA の 重合開始機構を解明しようとした。

\section{2. 実験方法}

\section{1 試 薬}

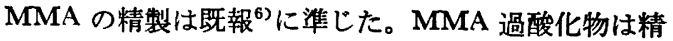
製 MMA を室内散光下に一定時間放置して作製した。 クレーは主として村上粘土鉱業社製のスーパーベン（純 モンモリロナイト, 粒径 5〜40 $\mu, \mathrm{pH} 4.5$ ) を使用した。 比較のために, 種々のメーカーの酸性白土, ベントナイ ト，カオリン，タルクなども用いた。また，2.3の方法 に従って，それぞれのクレーを酸処理およびアルカリ処 理したものについても検討した。アセトン, ベンゼンな どの溶媒は試薬特級（和光純薬(侏）をそのまま用いた。 また，水はイオン交換水を蒸留して用いた。

\section{2 重 合}

重合方法は既報 ${ }^{5}$ に準じた。水添加系での重合におけ る水分の調整は，末処理クレーについては水(16.5 wt\%) 


\section{クレーによるメタクリル酸メチルの重合}

を含むクレーをそのまま用い，乾燥クレー $\left(300^{\circ} \mathrm{C} ， 2\right.$ 時 間）についてはクレーを一定湿度中に放置して水分を吸 收させるか，あるいはクレー0.5 g に対して $0.5 \mathrm{ml}$ の水 を直接添加するかの方法によった。

\section{3 クレーの酸処理およびアルカリ処理}

クレーの酸処理およびアルカリ処理は, クレー $100 \mathrm{~g}$ に対して $0.2 \mathrm{~N}$ の塩酸水溶液あるいは水酸化ナトリウム 水溶液 $500 \mathrm{ml}$ を用い，パイレックス製ビーカー中， 90 $\sim 100^{\circ} \mathrm{C} て ゙ 1$ 時間加熱した後, 上澄液を口別し, さらに, この操作を 2 回繰り返した。その後，クレーを十分に水 洗し， $130^{\circ} \mathrm{C}$ で乾燥させ，100メッシュ以下に粓径を整え た。なお，末処理のクレー（スーパーベン）についても 同様に, 水だけで上述の方法に従って, 洗浄し, 粒径を 同一にした。

\section{$2.4 \mathrm{MMA}$ 過酸化物の定量およびクレーの pH の} 測定

MMA 過酸化物の定量は，既報卓した Wagner らのヨ ード法”によった。また，クレーの $\mathrm{pH}$ はクレー2.5 g を 純水 $50 \mathrm{ml}(\mathrm{pH}$ 6.88) 中に慗蜀させて㲘濁液の $\mathrm{pH}$ を $\mathrm{pH}$ メーター(堀場器械俐)で測定して求めた。

\section{5 クレーによる MMA 過酸化物の吸着およひ}

MMA 過酸化物级着クレーのアセトン抽出

クレー $2 \mathrm{~g}$ を MMA 過酸化物を含む MMA $20 \mathrm{ml}$ 中 に分散して振とうし,一定時間後, MMA とクレーとを口 別して MMA 中の MMA 過酸化物量を定量し, MMA 過酸化物の減少量をクレーに対する MMA 過酸化物の 吸着量とした。一方, MMA 過酸化物を吸着したクレー をアセトン $20 \mathrm{ml}$ に浸せきして MMA 過酸化物をアセ トンで抽出し，この操作を $2 \sim 3$ 回繰り返してMMA 過 酸化物のアセトン抽出量を求め, この值をクレー中に存 在した過酸化物量とした。

\section{3. 実験結果およひ考察}

\section{1 クレーの種類と重合開始能}

クレー（酸性白土）による MM4の重合において，既 報らに示したように水分および MM4 過酸化物がクレ 一と共存すれば，その重合速度は著しく增大したが，用 いた酸性白土の種類によっては, 必ずしも重合速度の大 きい結果は得られなかった。その原因として，クレ一の 酸性度 $(\mathrm{pH})$ あるいは水分含有量の相違が一応考えられ る。そこで，まず，この点を明搉にするために，種々の クレーの $\mathrm{pH}$ および含水率とクレーの重合開始能との関 係を検討した。Table 1にこれらの結果を示した。

既報5)で使用した酸性白土は Table 1 の和光 I に相当 しこれは重合開始能があったが，同じメーカーの酸性 白土でも和光IIに重合開始能はなかった。ここで倹討 した酸性白土のうち, 重合開始能があったのは和光 Iお よび村上のクレーのみであった。また，重合開始能のあ
Table 1. Kinds of clay and initiation power of polymerization. ${ }^{\text {a) }}$

\begin{tabular}{|c|c|c|c|}
\hline Kinds of clay & $\mathrm{pH}$ & $\begin{array}{l}\text { Moisture } \\
\text { content } \\
(\%)\end{array}$ & $\begin{array}{c}\text { Conversion } \\
\text { after } 7 \mathrm{hr} \\
(\%)\end{array}$ \\
\hline Acid clay (Wako I) & 4.8 & 10.4 & 65.0 \\
\hline Acid clay (Wako II) & 6.9 & 7.9 & 2.6 \\
\hline Acid clay (Kishida) & 6.7 & 15.7 & 2.3 \\
\hline Acid clay (Shimakyu) & 6.4 & 8.1 & 7.2 \\
\hline Acid clay (Yonəyama) & 6.6 & 5.9 & 2.2 \\
\hline $\begin{array}{l}\text { Acid clay (Yoneyama) } \\
\text { acid treatment }\end{array}$ & 5.2 & 一 & 35.0 \\
\hline Acid clay (Murakami) & 4.5 & 16.0 & 52.5 \\
\hline $\begin{array}{l}\text { Acid clay (Murakami) } \\
\text { acid treatment }\end{array}$ & 3.6 & - & 10.3 \\
\hline $\begin{array}{l}\text { Acid clay (Murakami) } \\
\text { alkali treatment }\end{array}$ & 9.2 & 一 & 0.5 \\
\hline Bentonite (Wako) & 9.0 & 7.6 & 0.5 \\
\hline $\begin{array}{l}\text { Bentonite (Wako) } \\
\text { acid treatment }\end{array}$ & 4.2 & - & 33.0 \\
\hline Kaolin (Yamazen) & 4.4 & 0.6 & $10.2^{b)}$ \\
\hline $\begin{array}{l}\text { Kaolin (Yamazen) } \\
\text { acid treatment }\end{array}$ & 3.4 & 一 & $7.9^{\mathrm{b})}$ \\
\hline Talc (Yamazen) & 8.3 & 0.2 & $7.3^{\mathrm{b})}$ \\
\hline $\begin{array}{l}\text { Talc (Yamazen) } \\
\text { acid treatment }\end{array}$ & 5.5 & - & $10.2^{b)}$ \\
\hline MMA only & - & - & $7.0^{\mathrm{b})}$ \\
\hline
\end{tabular}

a) Conversion after $10 \mathrm{hr}$. MMA $5 \mathrm{~m} l$, clay $0.5 \mathrm{~g}, \mathrm{H}_{2} \mathrm{O} 0.5 \mathrm{ml}, \mathrm{N}_{2}$ atmos-

b) phere, $70^{\circ} \mathrm{G}$

る末処理の酸性白土の $\mathrm{pH}$ は4.5 4.8であったが，重合 開始能のない酸性白土の $\mathrm{pH}$ は6.4〜6.9であり, 酸性を 示しているとは考えられなかった。一方，米山の酸性白 土 (pH 6.6) について酸処理すると (pH 5.2) 重合開始能 が現われできた。このことは， Na 型モンモリロナイト として知られでいる酸性白土と同じ構造をもつベントナ イトの酸処理物（pH 4.2）についても認められた。しか しながら,カオリン, タルクについては酸処理しても重 合開始能はなかった。

カオリンは酸性白土のようなシリケートーギプサイト ーシリケートの三層構造を有するモンモリロナイト族と 異なり, シリケートーギプサイトの二層構造で, ラメラの 上端は $\mathrm{OH}$ 基のみで占められ, ラメラ間の水秦結合は強 く,ラメラ間隙に水がほとんど吸収されないために重合 開始能がないものと思われる。

一方, タルクはギプサイト層のアルミニウム原子がマ グネシウムで置換された構造で酸性白土とまったく同様 のモンモリロナイト族に属するので, 酸処理することに より重合開始能が期待されるはずである。しかし, 重合 
率がやや大きくなるのみで重合開始能はないように思わ れる。これらのクレーの含水率が小さいことから考え て, やはり水の浸入しにくいラメラ間隙の性質に重合開 始能のないことが起因しているのかもしれない。なお， タルクとカオリンについてX線的にラメラ間隙の変化を 検討したが，乾燥クレーと吸湿クレーとの間にはなんら の差異も認められず,これらのクレー中に水が容易に浸 入しないことが証明された。

以上のことから，酸性を示し，かつラメラ間隙に水分 を吸収できるクレーが重合開始能を示すことがわかり， 重合の開始にはラメラ間陌の存在することが必要である

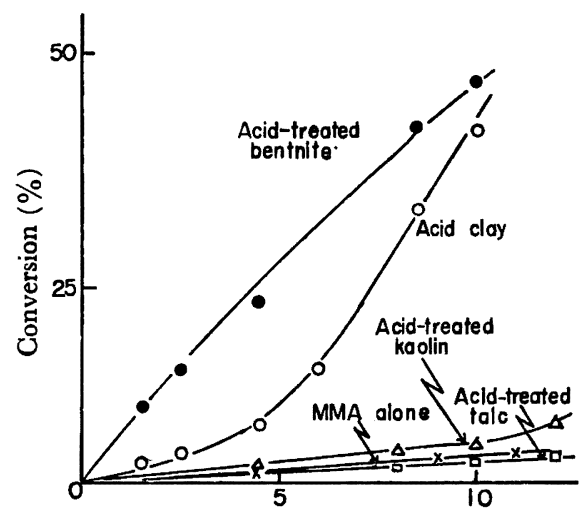

Polymerization time (hr)

MMA $5 \mathrm{ml}$, clay $0.5 \mathrm{~g}, \mathrm{H}_{2} \mathrm{O} 0.5 \mathrm{ml}$, $\mathrm{N}_{2}$ atmosphere, $70^{\circ} \mathrm{C}$

Fig. 1. Polymerization of methyl methacrylate initiated by acid-treated clay.

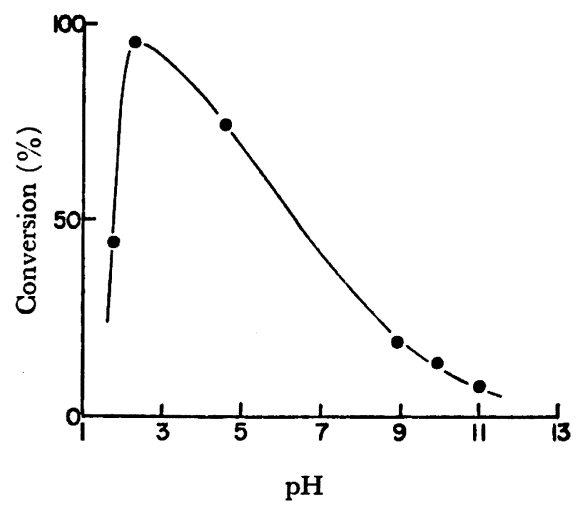

Clay $0.5 \mathrm{~g}$, MMA $5 \mathrm{ml}, \mathrm{H}_{2} \mathrm{O} 5 \mathrm{ml}$,

Clay- $\mathrm{H}_{2} \mathrm{O}$ (acid or alkali) $48 \mathrm{hr}$ dipping

Polymerization $15 \mathrm{hr}, 70^{\circ} \mathrm{C}, \mathrm{N}_{2}$ atmosphere

Fig. 2. Polymerization of MMA initiated by clay treated with acid or alkali.
ことが示唆された。Fig. 1 には, 村上のクレー, および それぞれ酸処理したベントナイト，タルク，カオリンに よる MMA の重合の重合率曲線を示したが，この図か らも明らかなよらに, 酸性白土と酸処理したベントナイ トのみ重合し, 酸処理したカオリン, タルクでは重合し なかった。すなわち, クレーの重合開始能とクレーの種 類（構造, ラメラ間隙, 水分含有量）との関連がよくわ かる。

さらに, Fig. 2 には重合に及ぼす系の $\mathrm{pH}$ の影畀を示 した。 $\mathrm{pH}$ の調節はすべて塩酸水溶液および水酸化ナト リウム水溶液で行なった。アルカリ性領域では重合速度 は非常に小さかったが，酸性になるほど重合速度は增大 し, pH 2.5 で最大となった。しかし, それ以下のpHで は逆に重合速度は低下した。このように, ある $\mathrm{pH}$ 領域 でのみよく重合することは興味深いことである。

\section{$3.2 \mathrm{MMA}$ 過酸化物のクレーへの吸着およひ脱着}

前報らに拈いて, クレーに MMA 過酸化物がよく吸着 する現象を認めた。一方, 酸性を示すクレーは MMA を重合させるが，中性またはアルカリ性を示すクレーは 重合させないことを 3.1 で認めたので, この重合性の差 異が MMA 過酸化物のクレーに対する吸着現象となん らかの相関関倸があるかどうかを検討した。以下の実験 においては重合開始能の著しかった村上の酸性白土をそ のまま酸性クレーとして, 一方, 水酸化ナトリウムで処 理したものを塩基性クレーとして用いた。

\subsubsection{MMA 過酸化物のクレーへの吸着}

Fig. 3 には, MMA 過酸化物を含む MMA 中にクレー

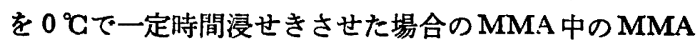
過酸化物滥度の時間的変化を示した。MMA 単独系であ ると過酸化物量の変化はほとんどなかったが，クレーが 存在すると浸せきのごく初期(吸着時間 0 時間)において

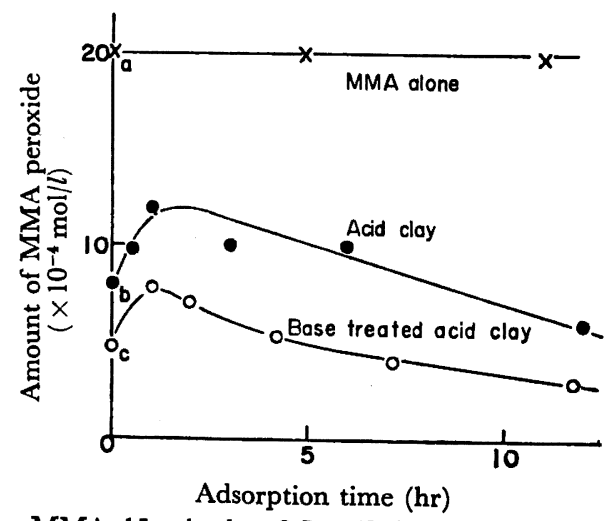

MMA $15 \mathrm{ml}$, clay $0.5 \mathrm{~g}\left(300^{\circ} \mathrm{C}, 2 \mathrm{hr}\right.$ dry $)$ $\mathrm{N}_{2}$ atmosphere, $0^{\circ} \mathrm{C}$

Amount of MMA peroxide : $2.02 \times 10^{-8} \mathrm{~mol} / l$

Fig. 3. Adsorption of MMA peroxide in MMA by clay. 
過酸化物量は著しく減少 ( $\mathrm{a}$ 点から b 点および $\mathrm{c}$ 点へ) し，その後やや增加するが，ふたたびゅっくりと減少して いった。この傾向屽酸性クレーと塩基性クレーとでほぼ 同様であったが，塩基性クレーの方がバルク相の MMA 過酸化物の減少量は大きかった。MMA 中の MMA 過 酸化物の減少量をもって, 一応, クレーに対する吸着量 と考えると, クレーによる過酸化物の吸着速度は非常に 速く, かつ塩基性クレーの方が酸性クレーよりも速いこ とになる。なお, 吸着の初期で系中の過酸化物量の著し 、減少の後に, やや增加するのはクレー中のなんらかの 活性点に起因して過酸化物が新たに生成されたものと考 えられる。この点については,さらに, 3.3 で詳述する。 ところで塩基性クレーには重合開始能がなかったので， この結果はクレーによる MMA の重合性が MMA 過酸 化物の吸着量に比例しないことを意味する。しかし，重 合の開始には MMA 過酸化物が関与することを認めて いるので5),クレーの重合開始能はやはりクレーの MMA 過酸化物吸着能となんらかの関連があるのではないかと 考えられる。そこで, この点について, 次に検討した。

\subsection{2 クレー中の吸着 MMA 過酸化物の脱着}

クレーはMMA 過酸化物を容易に吸着する能力があっ たが，次に吸着の場がクレーの単なる表面であるか， あるいはクレーのラメラ間隙であるかを検討した。一般 に，極性溶媒はクレーのラメラ間隙に入りうるが，無極 性溶媒はクレーのラメラ間隙に入りえないことが知られ ている。Blumstein ${ }^{8)}$ はクレー存在下で MMA の触媒重 合を行ない,クレーのラメラ間隙には二分子層のモノマ 一が入り得て，そこで重合が開始し，やはり二分子層の MMA ポリマーが生成することをX線的に認め, さら に，ラメラ間隙の PMMA はベンゼンでは抽出できない が，アセトンでは一分子層のみ抽出できることを明らか にしている。

そこで，溶媒として無極性のベンゼンおよび極性のあ

Table 2. Extraction of adsorbed methyl methacrylate peroxide in the clay with benzene or acetone. ${ }^{\text {a) }}$

\begin{tabular}{c|c|c|c|c}
\hline No. & $\begin{array}{c}\text { Amount of } \\
\text { adsorption } \\
\text { (mol/g-clay) } \\
\times 10^{8}\end{array}$ & \multicolumn{3}{|c}{$\begin{array}{c}\text { Amount of extraction } \\
\text { (mol/g-clay) } \times 10^{8}\end{array}$} \\
\cline { 2 - 5 } & $\begin{array}{c}\text { extraction } \\
\text { with } \\
\text { benzene }\end{array}$ & $\begin{array}{c}\text { Ist } \\
\text { extraction } \\
\text { with } \\
\text { acetone }\end{array}$ & $\begin{array}{c}\text { 2nd } \\
\text { extraction } \\
\text { with } \\
\text { acetone }\end{array}$ \\
\hline 1 & 13.0 & 2.8 & 40.9 & 6.0 \\
2 & 10.7 & - & 47.5 & 18.0 \\
\hline
\end{tabular}

a) Adsorption conditions: MMA $20 \mathrm{ml}$, clay 2.0 $\mathrm{g}\left(300^{\circ} \mathrm{C}, 2 \mathrm{hr}\right.$ dry $), 6^{\circ} \mathrm{C}, 45 \mathrm{hr}$ dipping

Extraction conditions: Solvent $20 \mathrm{ml}, 6^{\circ} \mathrm{C}$, $45 \mathrm{hr}$ extraction
るアセトンを用い，MMA 過酸化物吸着クレーをこれら の溶媒に浸せきし,一定時間抽出することにより，MMA 過酸化物がクレーから脱着されるかどうかを検討した。 Table 2 にその結果を示した。

Table 2 から明らかなように, ベンゼンでは MMA 過 酸化物はほとんど脱着されなかったが，アセトンでは多 量の MMA 過酸化物が脱着された。アセトンで抽出可 能であったことから，MMA 過酸化物はクレーのラメラ 間隙に吸着されていると推定される。さらに， Table 2 から，アセトンで脱着された MMA 過酸化物量は最初 に吸着された MMA 過酸化物量よりも著しく多いこと がわかった。一方，ベンゼンで抽出を試みた MMA 過 酸化物吸着クレーを，さらにアセトンで抽出すると，や はり最初に吸着された量よりも多い MMA 過酸化物が 脱着された。これらのクレーを，さらに，アセトン抽出 を繰り返すと,なお,かなりの過酸化物が脱着された。こ のことから，アセトンによる抽出操作の間にアセトンの 過酸化物が生成された可能性があり，そのために脱着量 が吸着量よりも多くなったのではないかと考えられたの で, アセトンークレー系で空実験を行なったが, 過酸化 物の生成は認められなかった。

クレーのラメラ間隙には MMA過酸化物以外にMMA モノマーも同時に浸入していることは明白であり，この 場合のラメラ間隙には，MMA および MMA 過酸化物 以外の何ものも存在しないはずである。それゆえ，この 場合, ラメラ間隙に存在する MMA がクレーのラメラ 間隙に存在するなんらかの活性点の作用により, 吸着の 過程ですでに MMA 過酸化物に変化したためではない かと考えられる。

このように考えると, Fig. 3 において, MMA 中の MMA 過酸化物濃度が吸着のごく初期に吸着によって著 しく減少した後の若干の增加現象がある程度理解できる のではなかろうか。

\section{3 クレーラメラ間陌での MMA 過酸化物の生成}

前節で明らかにしたように, MMA 過酸化物吸着クレ 一をアセトンで抽出した場合, 抽出液中には吸着量より も多い量の MMA 過酸化物が抽出され，その原因は MMA 過酸化物がクレーのラメラ間隙で新たに生成した ためであると考えた。しかも，この生成は低温，短時間 で起こることを認めた。そこで，この現象とクレーの重 合開始能との関連について，若干の検討を加えた。

Fig. 4 には, クレー量を一定にして MMA 過酸化物 初浱度を変化させた場合の吸着過酸化物量およびアセト ン抽出過酸化物量との関係を示した。Fig. 4 から明らか なように, 過酸化物初簧度が増加すればするほど吸着量 も増大し，同時に抽出過酸化物量も増大した。また，48 時間後には吸着量は系中に存在した MMA 過酸化物量 にほほ等しく，いいかえれば，MMA 相には MM】 過 
酸化物がほとんど存在しないことになる。したがって， MMA 相からの重合の開始はほとんど不可能であること がわかる。また，吸着量と抽出量との関係からわかるよ うに, 吸着量とほぼ等量の過酸化物が新たに生成されて いる。これらの事実はクレー存在下での MMA の重合

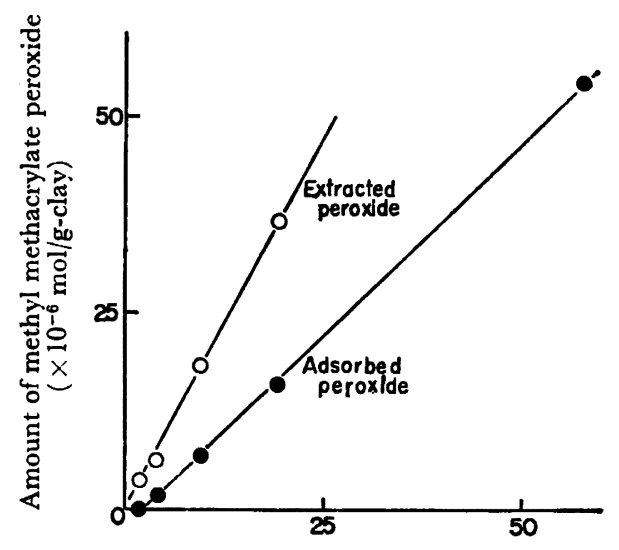

Initial concentration of MMA peroxide $\left(\times 10^{-4} \mathrm{~mol} / l\right)$

Adsorption conditions: MMA $20 \mathrm{ml}$, clay, $2.0 \mathrm{~g}$, $\left(300^{\circ} \mathrm{C}, 2 \mathrm{hr}\right.$ dry) $6^{\circ} \mathrm{C}, 48 \mathrm{hr}$ dipping

Extraction conditions : acetone $20 \mathrm{ml}$ each of solvent for 3 times, $6^{\circ} \mathrm{C}, 24 \mathrm{hr}$ extraction

Fig. 4. Effect of initial concentration of methyl methacrylate peroxide on the adsorption of methyl methacrylate peroxicie by acid clay.

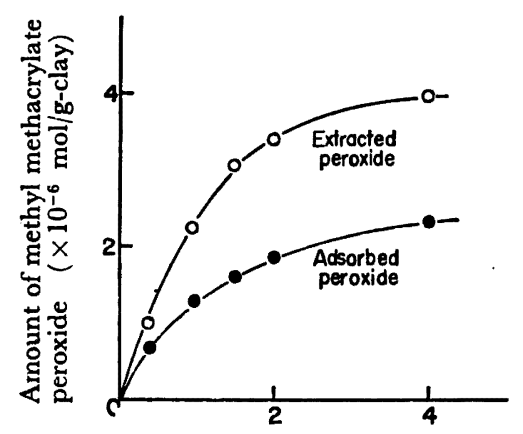

Amount of clay $(\mathrm{g})$

Adsorption conditions: MMA $20 \mathrm{ml}, 6^{\circ} \mathrm{C}, 24 \mathrm{hr}$ dipping, inital concentration of MMA peroxide $24.7 \times 10^{-4} \mathrm{~mol} / l$, clay $\left(300^{\circ} \mathrm{C}, 2 \mathrm{hr}\right.$ dry $)$

Extraction conditions: $20 \mathrm{ml}$ each of acetone for 3 times, $6^{\circ} \mathrm{C}, 24 \mathrm{hr}$ extraction

Fig. 5. Effect of the amount of acid clay on the adsorption of methyl methacrylate peroxide in methyl methacrylate.
がクレー内部で開始され，しかも重合速度が MMA 過 酸化物濃度に依存するという事実を説明するのに好都合 である。

Fig. 5 には, さらに同様な観点から, 過酸化物初浱度 を一定にしてクレー量を変化させた場合の結果を示し た。Fig. 5 から明らかなように, 吸着量はクレー量の増 加とともに増大し，同時に抽出量も増大した。このこと は重合速度がクレー量に依存したことと関連があるよ5 に思われる。

一方, Fig. 6 には, 種々の $\mathrm{pH}$ をむつように処理した クレーについての吸着実験を行ない，クレーの $\mathrm{pH}$ とク レー中での MMA 過酸化物の生成量との関係を検討し た結果を示した。なお，Fig. 6 には，比較のために吸湿 クレーについての結果も併記した。Fig. 6 から明らかな ように, 乾燥クレーの場合, $\mathrm{pH}$ が減少して酸性を示す ほど MMA 過酸化物の吸着量に対する抽出量の比は大 きくなった。すなわち, クレーの $\mathrm{pH}$ が酸性になるほど 新たに生成される過酸化物量が多くなることになる。こ のことは，クレー存在下での重合において， pH が酸性 領域において重合がよく進む事実と良い相関関係にあ る。一方, 吸湿クレーの場合には中性またはアルカリ性 領域で, その比，すなわち， MMA 過酸化物の生成の程 度は乾燥クレーの場合と大差ないが, $\mathrm{pH}$ が3〜 5 の酸 性領域では著しく減少している。これは水添加系では MMA 過酸化物が新たに生成しないためではなく，生成 した過酸化物が水の存在で分解してしまったためである と考えた方が妥当である。もし，この仮定が正しけれ ば,クレー存在下での MMA の重合が水の存在下で著 しく増大する事実を説明するに好都合である。このよう な過酸化物の分解が水の存在下で促進されることに関し て, 箕浦ら ${ }^{9)}$ はアクリルアミド過酸化物について認めて おり,われわれも ${ }^{10)}$ アクリル酸, メタクリル酸, アクリ ル酸メチル，その他のモノマー過酸化物について認めて いる。そこで, 実際に水がどの程度 MMA 過酸化物の分 解を促進するかという点について，次に検討した。

\section{$3.4 \mathrm{MMA}$ 過酸化物の分解}

クレー中に吸着あるいはクレー中で生成された MMA 過酸化物の分解速度は水の有無によって著しく異なると 考えられる。そこで, 酸性クレーと塩基性クレーとにつ

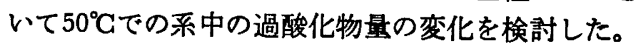

Fig. 7 には, 酸性クレーについての MMA 相および クレー中の MMA 過酸化物量の変化を, 水の存在下お よび不在下で比較検討した結果を示した。Fig. 7 から明 らかなように, MMA単独系では過酸化物量は溶存酸素 の影響でかなり增加している。ところが，クレー添加系 ではクレー添加直後ですでに MMA 相中の過酸化物量 は $\mathrm{a}$ 点から b 点（乾燥クレー）あるいは $\mathrm{c}$ 点（吸湿クレ 一）に減少しており,その後, 時閒の経過とともに徐々 


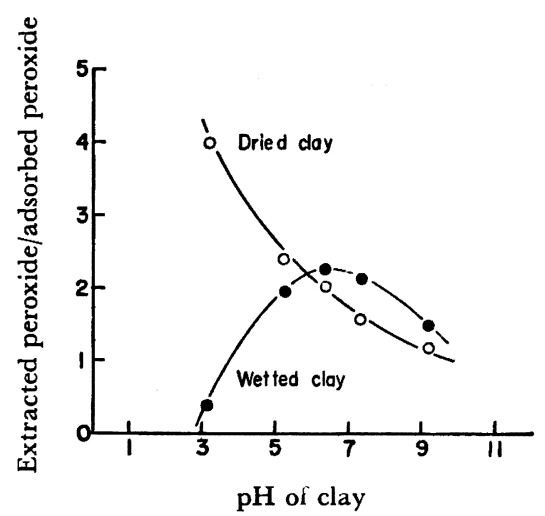

Adsorption conditions: MMA $20 \mathrm{ml}$, clay $2.0 \mathrm{~g}$, $6^{\circ} \mathrm{C}, 48 \mathrm{hr}$ dipping

Extraction conditions : acetone $20 \mathrm{ml} 3$ times, $6^{\circ} \mathrm{C}, 24 \mathrm{hr}$ extraction

Fig. 6. Effect of $\mathrm{pH}$ of clay on the ratio of extracted peroxide to adsorbed peroxide.

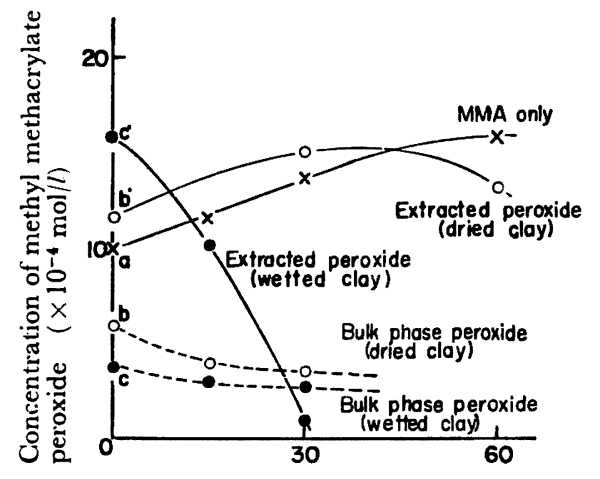

Adsorption time (min)

Adsorption conditions: MMA $20 \mathrm{ml}$, clay $2.0 \mathrm{~g}$, $50^{\circ} \mathrm{C}$, dried clay; $300^{\circ} \mathrm{C}, 2 \mathrm{hr}$, wetted clay; 20 , wt $\%$ water

Extraction conditions: acetone $20 \mathrm{ml}, 6^{\circ} \mathrm{C}, 24 \mathrm{hr}$ extraction

Fig. 7. Effect of water on the rate of decomposition of methyl methacrylate peroxide in the acid clay.

に減少した。この過酸化物減少量が吸着量に相当する が，吸湿クレーの方が初期の吸着量は若干多いようであ る。これに対して, アセトン抽出液中の過酸化物（クレ 一に吸着あるいはクレー中で生成) は初期において $\mathbf{b}^{\prime}$ 点 （乾燥クレー）および $c^{\prime}$ 点（吸湿クレー）であったが, 乾燥クレーではやや増加した後減少する傾向にあったの に対して, 吸湿クレーでは最初から著しく減少した。こ のことから, 水の存在下でクレー中の MMA 過酸化物
の分解速度は非常に大きいことがわかる。なお，水の影 響をさらに検討するため，クレー不在下で MMA-水系 （水は MMA の溶解度以下）での MMA 過酸化物の分

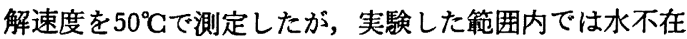
下での結果と大差なく，水の MMA 過酸化物の分解に 及ぼす影響は認められなかった。なお，この点について はさらに検討する予定である。

一方, Fig. 8 には, アルカリ処理した塩基性クレーを 用いた場合の同様の結果を示した。Fig. 8 から明らかな ように，吸着過酸化物量に関しては酸性クレーとほぼ同 様の傾向を示した。ところが，クレー中の過酸化物は乾 燥クレーについては酸性クレーと大差ないが，吸湿クレ ーについては, 酸性クレーが MMA 過酸化物の著しい 減少を招いたのに対して，ほとんど減少しなかった。す なわち, 塩基性クレーでは, 水が存在してもクレー中の 過酸化物は分解しないことがわかり，この点が酸性クレ 一と著しく異なった。この原因については，目下，検討 中である。

\section{4. 結言}

クレー存在下での MMA の無触媒重合において, 重 合の開始には, MMA 過酸化物, クレー, 水の三者が必 要であることを前報 ${ }^{5)}$ で認めたが，本報告では，MMA 過酸化物のクレーに対する吸着現象を検討し，重合開始 に及ぼすそれぞれの因子の役割をある程度明らかにする ことができた。すなわち，MMA 過酸化物はクレーに選 択的に吸着され，クレー中では MMA 過酸化物の吸着 量に応じて，新たな過酸化物が生成され，水はクレー中

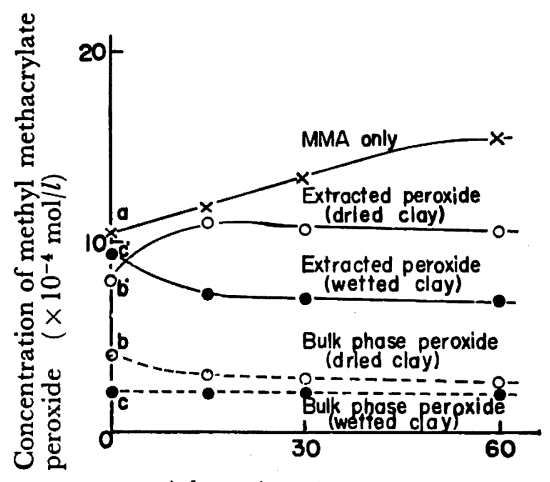

Adsorption time (min)

Adsorption conditions: MMA $20 \mathrm{ml}$, clay $2.0 \mathrm{~g}$, $50^{\circ} \mathrm{C}$, dried clay; $300^{\circ} \mathrm{C}, 2 \mathrm{hr}$, wetted clay; $20 \mathrm{wt} \%$ water

Extraction conditions: acetone $20 \mathrm{ml}, 6^{\circ} \mathrm{C}, 24 \mathrm{hr}$, extraction

Fig. 8. Effect of water on the rate of decomposition of methyl methacrylate peroxide in the base treated acid clay. 
の MMA 過酸化物を分解することを認めた。さらに水 による過酸化物の分解は酸性領域で著しく促進される が，塩基性領域では抑制されることを明らかにした。し かしながら，なにゆえ，MMA 過酸化物が新たにクレー 中で生成されるか，また，塩基性領域で水が存在しても MMA過酸化物は分解しないかなどの詳細はいまだ不明 であり，目下，検討中である。これらの点については， クレーのラメラ間隙に存在する活性点についての検討と ともに次回で報告したい。

付記 本報告は第 19 回高分子学会年次大会 (東京, 19 70)で発表したものであり,それに一部を追補した。

\section{文献}

1) H. B. Bittles, A. K. Chaudhuri, S. W. Benson:
J. Polymer Sci., A2, 1221, 1847, 3208 (1964)

2) D. H. Solomon, M. J. Rosser: J. Appl. Polymer Sci., 9, 1261 (1965)

3) H. Z. Fridlander: J. Polymer Sci., C4, 1291 (1964)

4) 松本恒隆, 酒井五十治, 有原正彦: 高化， 26, 378 (1969)

5) 松本恒隆, 有原正彦: 高化, 26, 896 (1969)

6) 松本恒隆, 宗 伊佐雄, 岩井 勇: 高化, 25, 127 (1968)

7) C. D. Wagner, R. H. Smith, E. D. Peter: Ind. Eng. Chem. Anal. Ed., 19, 976 (1947)

8) A. Blumstein: J. Polymer Sci., A3, 2653 (1965)

9) 中野明彦，箕浦有二：工化, 71, 732 (1968)

10）松本恒隆: 未発表

\title{
Polymerization of Methyl Methacrylate with Acid Clay
}

\author{
II. Adosorption of Methyl Methacrylate Peroxide onto Acid Clay \\ by Tsunetaka Matsumoto*, Isao Mune*, and Takanori Kimura*
}

It was previously found that the polymerization of methyl methacrylate (MMA) was initiated with clay-MMA peroxide-water system. In this paper, in order to clarify the initiation mechanism of this polymerization, the phenomenon of adsorption of MMA peroxide onto the clay was mainly studied. The main results obtained were as follows: The polymerization of MMA was initiated only with acid clay which gave the $\mathrm{pH}$ range $3 \sim 5$ in aqueous media. MMA peroxide was easily adsorbed onto the clay, regardless of its $\mathrm{pH}$. Meanwhile, in case of the extraction of MMA peroxide adsorbed onto the clay with acetone, the extracted amount of MMA peroxide became larger than the adsorbed amount of MMA peroxide, but in case of the extraction with benzene, the extracted amount of MMA peroxide was little. Moreover, both the adsorbed amount of MMA peroxide and the extracted amount of MMA peroxide with acetone were increased with the increase of the initial amount of MMA peroxide and of the amount of clay. In the dried clay, the ratio of the extracted amount of MMA peroxide to the adsorbed amount of MMA peroxide became remarkably large in the acidic $\mathrm{pH}$ range. In wetted clay, however, the ratio became very small in the acidic $\mathrm{pH}$ range. The rate of decomposition' of MMA peroxide in the clay was enhance 1 only in the case of presence of water in clay which gave acidic $\mathrm{pH}$ range.

From these facts it is reasonable to conclude that MMA peroxide adsorbed in the lamella gap of clay and formed newly is decomposed only in the case of presence of water in the clay having an acidic pH range to initiate polymerization of MMA.

KEY WORDS Acid Clay/Methyl Methacrylate/Bulk Polymerization/Methyl Methacrylate Peroxide/Adsorption/Extraction/Clay Lamella Gap/Decomposition of Monomer Per-
oxide/Behavior of Water/

\footnotetext{
* Department of Industrial Chemistry, Faculty of Engineering, Kobe University (Rokkodai-cho,
Nada-ku, Kobe)
} 